\title{
Sources of financial synchronism: Arbitrage theory and the promise of risk-free profit
}

\section{Andreas Langenohl}

Justus Liebig University Giessen, Germany

\begin{abstract}
This article argues that the temporality of the financial economy ought to be seen as radically synchronistic. 'Synchronism' refers to both an epistemological and practical approach that addresses finance neither with a view to the past nor to the future, but is instead focused on the moment that a financial transaction is settled (i.e., the horizon of trading). From this perspective, the article expands the scope of current social theorizing on financial markets, which is characterized by a preoccupation with the futurity of financial markets and products. It suggests that financial synchronism can be traced back to certain developments in economic theory since the so-called 'marginalist revolution', which enabled the transfer of a certain optics informing market theories into financial practices. On these terms, financial synchronism is interpreted as a powerful social imaginary that crucially mediates the way contemporary societies face the contingency of the future.
\end{abstract}

\section{Keywords}

Finance, trading, temporality, synchronism, arbitrage, risk

\section{Introduction: Beyond the valorization of futurity}

Recent work in the sociology of finance has characterized financial markets as fundamentally future-oriented in a bid to challenge financial economics as the dominant paradigm for understanding financial markets. In contrast to the latter, which has held that investment actors' view on the future can be regarded as 'rational' insofar as they make complete use of all available information regarding financial markets (Fama, 1970; Fama and Miller, 1972), sociologists argue that expectations are a mode of orientation that helps investors maneuver in the face of a characteristically uncertain future (Baecker, 1999; Esposito, 2010; Langenohl,

\section{Corresponding author:}

Andreas Langenohl, Department of Sociology, Justus Liebig University Giessen, Karl-Gloeckner-Str 21 E, D-35394 Giessen, Germany. Email: andreas.langenohl@sowi.uni-giessen.de 
2010; Beckert, 2014). Radicalizing this argument, Oliver Kessler (2010, 2013) has pointed out that neoclassical modeling in economics is based on an epistemic transformation of fundamental uncertainty about future events into calculable risks and probabilities - a transformation that, according to Kessler, is in fact an economically productive misunderstanding of the nature of uncertainty (see also Lee and LiPuma, 2002). Thorsten Strulik (2006), proceeding from a similar characterization of the future as a realm of uncertainty, arrives at the somewhat different conclusion that interpretive patterns that govern financial agency and financial regulation ought to be freed from normative expectations, arguing for a 'cognitive mode in global finance' (Strulik and Wilke, 2006). ${ }^{1}$

This article aims at complicating the characterization of financial markets as oriented toward the future. Its main thrust is that the diagnosis of financial futurity has to be complemented by one of financial synchronism because large sectors of economics as a science, and the financial economy as a field of practice in contemporary societies, have been oriented toward a radical synchronism, especially in trading. Here I am taking up the diagnosis of Wayne Hope (2009, 2011), who argues that contemporary financial markets have maneuvered themselves into a contradiction with the profit logic of industrial capitalism: while the latter affords a certain amount of time in order to generate surplus value from the production of commodities (including the exploitation of workers), and thus demands a certain temporal stabilization of the production sequence, financial 'real-time' capitalism is based on the instant realization of profits. There is, for example, a structural conflict between the speed with which trades are made on the international foreign exchange markets and the considerably slower rhythms of the accounting back office which has to administer those trades (Lépinay, 2007).

This article takes a closer look at the sources of this financial synchronism, paying particular attention to its significance for the self-understanding of modern societies. It will argue that financial synchronism can be traced back to certain developments in economic theory since the inception of the so-called 'marginalist revolution' in the 1870s. The hypothesis I pursue is that financial synchronism is not simply the outflow of a particularly greedy way of making money (cf. Honegger et al., 2010), but the transfer of a certain optics informing market theories into financial practices. From this perspective, the article interprets financial synchronism as a powerful social imaginary (Taylor, 2002) that crucially mediates the way contemporary societies face the contingency of the future.

\section{Mathematical finance and the role of arbitrage in pricing theory}

To exemplify the significance of financial synchronism in economic theory, I would like to briefly outline a core approach in contemporary financial economics that underpins the acceleration of algorithmic trading on electronic markets: mathematical finance. Mathematical finance promises to build upon one of neoclassical economics' main operations, which is the 'pricing' of products traded on competitive markets. The operation of pricing in financial markets relies fundamentally on the relation between supply and demand for a given product at a given time, as well as on the ensuing orientation of market actors to those prices (Hardie, 2004; Langenohl, 2010), but it is also based on certain preconditions that allow financial products to become interrelated in the first place so that prices can emerge. This applies, for instance, to the institutionalization of calculative categories that function as frames for pricing (cf. Callon, 1998), as well as to the production of comparability of different financial products (Beunza et al., 2006, 2008). However, prior to such institutionalizations, pricing on financial markets 
depends on the confrontation between hypothetical prices generated by theoretical models (for instance, those of mathematical finance) and empirical prices observed in the market.

The ability to perform such comparisons between a theoretically generated and an empirically observed price, and to make a profit from this, is rooted in the so-called 'marginal revolution' in economics that took place at the end of the nineteenth century, one of whose main impacts was the collapse of the concept of value into the concept of price. While classical political economy and its critique had tried to deduce the value of a given item from the shares of capital, labor, and agricultural land that had flowed into its production, marginalist theory held that the value of an item is, in theory, identical with the highest price at which it can be sold (Mattick, 1973). In line with its subjectivist theory of value, neoclassical economics, as Friedrich von Wieser explained in 1893, tried to develop "a point of view from which price becomes a social judgment of value [that is, becomes decoupled from other factors like labor etc.], [which] really amounts to a disregard of all the individual differences [...] which separate price from natural value" (Wieser 1989: 61, quoted in Bockman 2011: 23; emphasis added). This lends itself to an interpretation that neoclassical economics was epistemologically based on a notion of 'price' which was theoretically identical with 'value', yet which also allowed differences to be observed between theoretically generated prices ("natural value' in the above quote) and empirical prices. There exists, therefore, an epistemological continuity between neoclassical economics and financial pricing models that operate on a constant comparison of hypothetically generated prices and empirical prices (see Millo and MacKenzie, 2003).

Pricing thus can be regarded as a hinge that interconnects economic theory with economic practice because hypothesized and empirical prices are treated as if they were located on the same epistemological plane. Neoclassical theory boils down to this core achievement: a theory capable of generating a virtual reality of valuation, which is epistemologically short-circuited with empirical reality, and thereby allows a comparison between hypothesis and reality (which is supported by epistemic devices that enable that comparison). This comparison can be put to two very different uses: it can be used to improve the models, or it can be used to gauge whether an empirical price might not be justified by the model, and hence traded on.

Mathematical finance is a logical continuation of the neoclassical program. It develops theories and models that allow the generation of hypothetical prices that can then be compared with empirical prices. The main innovation of mathematical finance, though, is that it breaks down the products traded on financial markets into virtual components defined by different profiles of valuation - in particular, by different categories of risk. In this way, products that would seem quite clearly defined - like a company share or a sovereign bond become disaggregated into components that can be rearranged and traded independently of their original assemblage in the share or the bond. Mathematical finance thus enables a multiplication of comparisons between financial products, thus creating new markets and enlarging existing ones.

I will give a brief example of how mathematical finance achieves such disaggregation. Take a typical financial product: a company share. According to textbook wisdom in mathematical finance (Joshi, 2003; Černý, 2009), a company share consists of different components. The analytical basis on which to sort them out is the price of a sovereign bond, which for historical reasons counts as a risk-free asset in finance economics (cf. Boy, 2015). Proceeding from this epistemological basis, different types of risk are identified that together make up the total risk of a share. There is, first, the risk that the company might go bust. On financial markets, such risk is priced through a credit default swap, that is, an option to swap 
one credit default risk for another. Second, there is the risk that the share underperforms in comparison to other products. Such risk is priced through a put option, that is, the option to sell the share at a predefined price in order to insure oneself against a decline in value. Third, there is the complementary risk that the share performs better than expected, such that it would have been advantageous to buy more of it to start with. This risk is priced through a call option, that is, the option to buy the share at a predefined price in order to profit from a rise in value. Altogether, the company share consists of three types of risk, if compared with a sovereign bond (counting as a risk-free asset): credit default, decline in value, and rise in value.

The major consequence of mathematical finance is that, on the basis of this kind of analysis, a considerable multiplication of possibilities to confront empirical and hypothetical prices on financial markets is achieved. In other words, mathematical finance creates new markets and is thus a driver of 'financialization', understood in the sense of Leyshon and Thrift (2007: 98) as the "creation of a new asset stream". For instance, it becomes possible to price the share in comparison with the sum of its risk components, i.e., credit default swaps, put options, and call options, which can all be traded separately and re-packaged. If it turns out that the sum of the risk components is higher or lower than the share's price, then this can be read as an indication that the share is underpriced or overpriced, respectively. This, in turn, gives rise to the possibility of trading shares against the risk components they consist of.

It is important to stress that such trading between financial products takes place and realizes profits instantly. It is a core aspect of what in economics, financial economics, and the social studies of finance is called arbitrage. Scholars in the latter field have observed a lack of definition concerning arbitrage in financial economics (Hardie, 2004: 243). However, instead of trying to directly compensate for such lack of definition, they have tried to map the terrain of financial practices that involve one or more of the aspects usually referred to as related to arbitrage. Arbitrage is based on a comparison between the prices of two assets that are deemed comparable to each other and have been found to achieve different prices in different markets or market segments. In the ideal-typical case, one and the same asset is priced differently. For neoclassical economics (and mathematical finance as one of its heirs), the differential between two prices for the same, or two comparable, products points to 'inefficiencies' in markets or between markets. Arbitrage exploits this price differential, and at the same time helps to close it, thus contributing to the constitution of efficient markets (Hardie, 2004: 240-6).

Crucially, however, Beunza et al. $(2006,2008)$ have pointed out that the comparability between assets needs to be seen as socially constituted. Most contemporary arbitrage practices, they argue, do not refer to 'one and the same' product (like gold which may be priced differently in different markets) but to products that are construed as comparable in their market risk exposures (for instance, bonds of different states that are assumed to be exposed to the same market forces). In other words, comparability rests on an effort in persuasion, be it the persuasion of other market participants or their supervisors, such as the heads of arbitrage desks in investment banks and hedge funds (cf. Fenton-O'Creevy et al., 2005). Even the identity of 'one and the same' product must be verified and established, for instance, the construction of quality criteria for a given asset (like the purity degree of gold). Thus, arbitrage practices may maintain blurred boundaries with other financial practices, like speculation, depending on the persuasive effectiveness of the stipulation that two products are indeed comparable in their market risk exposures (Beunza et al., 2008).

However, arbitrage is assumed to contain considerably less risk than other trading practices, because it is based on the exploitation of already existing, as opposed to emerging 
and thus uncertain, price differentials. To be sure, it is not completely risk-free. For instance, the buyer of a given security might default on payment, or the information regarding price differentials might simply be incorrect. Still, arbitrage is free of market risks, that is, risks that emerge from pricing contingencies over time (Beunza et al., 2008). The argument that I wish to contribute to this discussion is this: Arbitrage maintains a relation to financial synchronism, inasmuch as the ideal-typical scene of arbitrage, understood as the realization of a profit free from market risk, is the instant buying and selling (or 'shorting' and buying, cf. Beunza et al., 2008) of a product or a set of comparable products which attain different prices in different markets. Arbitrage may also refer to trades not finalized on the spot, such as futures. However, as Hardie (2004: 243) points out, the timeframe of these risks still excludes market risk inasmuch as it is a "timeframe over which the profit is guaranteed". The important point thus is that market risks, i.e., those risks that stem from the unfolding of a market for the arbitraged products over time, are neutralized. Therefore, the 'synchronism' of arbitrage is grounded in the absence of market risk of contingent price fluctuations.

The synchronism of arbitrage and its active production by the construction of comparability illuminates a broader tendency of mathematical finance's theory and practice. Shifts in the market value of the commodity pose no risk for the trader because the commodity is never kept. For instance, if the mathematical analyses result in the establishment of a price differential between a share and the sum of its risk components traded independently, this is an opportunity to buy the share and immediately sell the risk components that it is composed of, or vice versa. Mathematical finance thus allows the multiplication of comparisons, of trading relations and of interconnections between different financial market segments. For instance, company shares and sovereign bonds can be directly arbitraged against each other because they share a certain type of risk (for instance, that of underperformance). More important for the present article, however, is that arbitrage is a radically synchronist trading practice. Contrary to the received financial wisdom of the Kostolany principle, whose stipulation that 'company shares outperform any other financial investment if they are held long enough' is based on comparing their present and future prices, mathematical finance views company shares exclusively from the perspective of the synchronous price differentials between themselves and the sum of their components. Thus, unlike pricing strategies that operate through the projection of price developments in the future (such as fundamental analysis, but also technical analysis; see Langenohl and SchmidtBeck, 2007), mathematical analysis creates a multitude of new arbitrage relations: the possibility of instantly comparing two present prices and instantly drawing profit from their differences.

Mathematical finance also displays that connection between economic theory and economic practice that has been labeled 'performativity' in the social studies of finance (MacKenzie et al., 2007; Callon, 2009). In short, the notion of performativity refers to the suggestion that economic theory, and in particular economic modeling, should be critically analyzed not so much with regard to its theoretical claim of correspondence - that is, the question of whether those models adequately depict what they claim to describe - but rather with respect to the effects they have on economic practice. In particular, the concept of performativity has been used in order to point to the continuities between neoclassical market models and trading practices, including digitized ones (cf. MacKenzie and Millo, 2003 for an influential contribution). While I will return to this discussion later on in the article, the example of mathematical finance and its intimate connection to arbitrage as a major instance of financial synchronism suggests that a deeper look into the history of economics may be illuminating. 


\section{Léon Walras: Economic statics and arbitrage}

In my genealogy of synchronism in economic theory, I will begin with one of the key figures of the marginalist revolution, Léon Walras, who, alongside William Jevons in Britain, pioneered a mathematical theorization and modeling of economic processes. The reason for choosing Walras as a point of departure is that he gave one of the first characterizations of arbitrage as a synchronist economic practice, and indeed based his theory in crucial respects on the concept of arbitrage. The key claim of marginalist economics has already been mentioned, which is that value equals the highest price at which a commodity can be sold. This puts the subjective desires of individuals at center stage, but not in the sense that they would be empirically relevant. Instead, marginalist theory holds that individuals on average compare their desire to consume a given product with the price at which it is offered, the 'price' being the utility of those products they would have to give away in order to purchase the product in question. In other words, value equals the price that forms at the margins of expected utility of individuals' desires.

Neoclassical theory has been reproached for being a stationary theory, that is, one that does not resonate with changes in markets, especially in historical perspective (Pribram, 1998: 971-78; Kirchgässner, 2008: 271-80; Vogl, 2010: 53-82). On its surface, however, marginalist theory does seem to imply change, as when the utility arising from the consumption of a given commodity decreases as satisfaction increases: "I postulate that intensive utilities always diminish from that of the first unit or fraction of a unit consumed to that of the last unit or fraction of a unit consumed" (Walras, 1954: 118). However, the process in which utility decreases through consumption is modeled not as a steady process but as a series of intervals:

\footnotetext{
I am assuming that, during this interval [in which consumption takes place], the utility, both extensive and intensive, remains fixed for each party, which makes it possible for me to include time implicitly in the expression of utility. Were this not the case and had I supposed utility to be a variable functionally related to time, then time would have had to figure explicitly in the problem. And we should then have passed from economic statics to economic dynamics. (Walras, 1954: 117, emphasis added)
}

We can see from this quote that Walras' insistence on a stationary theory of exchange brings with itself the need to model processes of change as intervals between which transactions can take place. Based on this hypothetical model, Walras (1954: 84) proposes a scenario that describes how prices form and transactions take place, that is, through a process of 'groping' (tâtonnement): "through the instrumentality of stockbrokers, commercial brokers or criers acting as agents who centralize transactions in such a way that the terms of every exchange are openly announced and an opportunity is given to sellers to lower their prices and to buyers to raise their bids". For Walras, prices form not so much through exchange but rather prior to exchange, because only when the price for two commodities in terms of one another becomes attractive for both sides does exchange take place. The process of 'groping' is one major component of Walras' stationary theory of pricing: 'groping' enables acts of exchange, but also separates them from each other into a "sequence of temporary equilibria" (Dome, 1994: 119). This means that each transaction is, in terms of temporality, strictly bound to a given present situation.

With Walras, we arrive at a picture in which a stationary model of economic equilibrium is achieved through a heuristic scenario that singularizes exchange transactions. Each transaction is the result of a process of redefining marginal utility and a process of 'groping' in which a price is fixed that is viable for both parties to the exchange. That is, exchange 
transactions are conditioned by intervals in which no exchange takes place and therefore, equilibrium price formation takes place not through, but prior to, the exchange.

Yet, at this point, Walras (1954: 162f.) approaches a contradiction, arguing that "the problem of exchange for which we have just given a theoretical solution is the selfsame problem that is solved empirically on the market by the mechanism of free competition". According to Walras (1954: 169, 173), this happens through "arbitrage": commodities are exchanged until a point is reached where demand for a certain commodity equals supply and the equilibrium price makes itself manifest. In other words, equilibrium price formation takes place through exchange, and constantly so; a clear contradiction to Walras' earlier observation that transactions are interrupted by temporal intervals in which utility is redefined through consumption and tâtonnement.

Why is this important? According to Walras (1954: 71), neoclassical theory's single task should be price formation because this is the only part of economics that can be rigorously mathematized. I have claimed above that neoclassical theory's interest in pricing creates a hinge between theory and practice. In Walras, we begin to see how this hinge works and what its temporal implications are. While the theory has to be stationary in order to model exchange in terms of equilibrium, it also opens a vista on empirical economic processes through the notion of arbitrage. My point is, now, that the functioning of this hinge implies a rigorously synchronist stance that applies to both theoretical modeling as well as to pricing mechanisms in trading practice. This is the case because arbitrage, which according to Walras manifests the hypothetical tâtonnement in concrete trading, is by definition exclusively oriented toward the present moment, exploiting price differentials between two marketplaces and thereby eradicating those differentials until equilibrium is reached.

Walras' marginalist theory of pricing invokes a synchronist conceptualization in a twofold way. On the one hand, the hypothetical model implies that exchange transactions are serial yet singular events, and attaches the constant process of utilization and desire to punctuated occasions. Transactions are synchronous executions of prices that have been formed in advance, and thus express a state instead of steering a process. On the other hand, the empirical mechanism that Walras sees as materializing the marginalist logic in reality is arbitrage, which of all trading practices is the one most rigorously bound to synchronism because it exploits price differentials within market space, not between different points in time. Arbitrage is therefore also the only trading practice that can generate risk-free profit, because the transaction, together with all implied obligations, is begun and finalized in the same instant.

\section{Friedrich von Hayek: Fleeting moments of opportunity}

Let me turn next to an economist who has come to stand, like probably no other, for a 'marketradical' (Oetsch, 2013) conception not only of the economy but of society at large: Friedrich von Hayek. Hayek is of interest here because an understanding of market exchange as a radically momentary and instantaneous transaction not only informs his economic theory but his philosophy of the social sciences as well.

Hayek develops his theory of market competition on the basis of a distinction between the economy and the market. The economy, strictly speaking, comprises only those actions of individuals through which they aim to sustain themselves by way of exchanging goods and services with other individuals. In other words, 'economy' is modeled after the Greek notion of oikonomia, that is, as household economy, and Hayek maintains that individuals know the 
local conditions and necessities under which they engage in transaction with others fairly well (Hayek, 1984a). In other words, the economy can be known by individuals. This is not the case with the market. On the market, individuals engage with other individuals through the communication of prices that are forming as a result of the actions of countless other individuals, whose rationales, motivations and necessities cannot be known by any observer. Hayek argues, however, that this is not a problem because the price carries all the information that individuals need in order to adapt their production and exchange practices to demand (Hayek, 1984b).

This argumentation challenges both economic theory and policy. If market prices are the result of countless individuals' actions and if those actions cannot be known except in their aggregate effect, then it becomes pointless for economic theory to claim to make mathematically precise predictions, just as it becomes harmful for economic policy to try to control the market mechanism as if it could be known. On this basis, Hayek challenges in particular econometric models that, as he sees it, form the core of Keynesian policies of economic governance (Hayek, 1984a). While he acknowledges the usefulness of algebraic renditions of the market as used in marginalist theory, he also cites Vilfredo Pareto, a disciple of Walras, as cautioning against a "numerical calculation of prices" on the basis of those models because "it would be 'absurd' to assume that we could ascertain all the data" (Hayek, 1984c: 271).

Instead, what happens on markets can only be understood as spontaneous processes of "adaptation" (Hayek, 1984a: 217), for which Hayek in an early text provides the following set of scenes:

The shipper who earns his living from using otherwise empty or half-filled journeys of tramp-steamers, or the estate agent whose whole knowledge is almost exclusively one of temporary opportunities, or the arbitrageur who gains from local differences of commodity prices - are all performing eminently useful functions based on special knowledge of circumstances of the fleeting moment not known to others. (Hayek, 1984a: 214, emphasis added)

The ways that individuals relate to the market is always radically bound to a respective present, which he calls the "fleeting moment". Hayek goes on to argue that in order to operate on a market, an individual neither feels the need nor faces the challenge to engage in consideration of why demand has changed: "All that is significant for him is how much more or less difficult to procure they [the demanded goods] have become compared with other things with which he is also concerned, or how much more or less urgently wanted are the alternative things he produces or uses" (Hayek, 1984a: 218, emphasis added). Summing up his argument, he states that "the economic problem of society is mainly one of rapid adaptation to changes in the particular circumstances of time and place" (Hayek, 1984: 217), while that adaptation always encounters "unforeseen changes" (Hayek, 1984b: 261; cf. Hayek, 1984c).

Accordingly, Hayek expresses some skepticism that economics - in its quality as a social science - can be grounded on mathematical calculations. But he does see merit in the algebraic formalizations of marginalist theory insofar as they articulate general relationships between economic parameters that are channeled into markets. All that economics can do, he argues, is to engage in "pattern predictions" (Hayek, 1984c: 270) without the ambition of arriving at numerically defined forecasts. This is because markets operate in a way that necessarily escapes oversight and epistemic penetration by any single actor or organization, since they are constituted by individual, highly contextualized, particularized, and momentary exchange practices. Hayek's "fleeting moment" thus leaves room neither for a consideration of 
the past reasons for changes in goods and services' prices, nor for speculations about future changes which of necessity must remain "unforeseen".

For the purposes of the present article, I want to stress the robustness of synchronist arguments in 'market-radical' economic theory. Walras based his theory of market pricing which according to him, is the only part of economics that can be mathematically calculated and thus is eligible for 'scientific' status at all - on a formidably synchronist argument, according to which prices form in instantaneous moments of price execution both in the hypothetical model and in empirical practice. If Hayek expresses doubts regarding the possibility of a mathematical forecast of prices for goods and services, ${ }^{2}$ he nevertheless reverts to the same temporality of the price: forecasting is impossible because individuals momentarily adapt their behavior to changes in supply and demand, and because these individual acts cannot be observed in their entirety apart from the prices they generate. The same synchronist conceptualization of price that encouraged Walras to analogize hypothetical and empirical acts of price formation in mathematical neatness now informs Hayek's skepticism regarding that very same mathematical formalization. Moreover, Hayek generalizes this synchronist price conceptualization into a social-theoretical outlook on mechanisms of social coordination.

\section{Harry Markowitz: Arbitrage as endpoint of portfolio theory}

My genealogy so far has discussed foundational figures of economic thought whose ambition was to come up with a general economic theory. However, since the second half of the twentieth century, financial economics has increasingly emerged as an autonomous sub-field of economics (Lounsbury, 2002, 2007; Preda, 2009), whose contributions have not least concerned understandings of economic temporality. I have already shown how contemporary mathematical finance is based on the consideration that pricing is not so much driven by assumptions about the inherent value of a given financial product, but by analyses of the risk profile of that product in comparison to other risk profiles. This analysis of the risks connected to investments is indeed the central distinctive feature of financial economics vis-à-vis general economic theory (Lee and LiPuma, 2004), which I now want to trace back to one of its foundational moments: Harry Markowitz's $(1952,1991)$ contributions to what came to be termed 'portfolio theory'.

According to Markowitz, the chance of a given set of investments (a portfolio) to perform better than others does not so much arise from a combination of particularly promising investments in terms of an above-average increase in value, but from a combination of investments whose overall risk of losing in value is below average. The aim, therefore, is to compose a portfolio of investments whose overall risk is lower than that of the market as a whole. Benjamin Lee and Edward LiPuma (2004: 147) argue that this theorization introduces an element of abstraction into finance theory, which decouples the notion of risk from concrete securities (such as shares or bonds) and re-renders it in the form of "stochastic differential equations". According to the authors, this new, abstract understanding of risk directly contributes to the constitution of intercomparability between financial products and hence to financial circulation:

[O]nce risk exists in an abstract form, it can take on the overarching role of helping to produce connectivity itself ... Abstract risk functions systematically because it interconnects the variegated forms of specific concrete risk, defining them as quantifiable through the same mathematics, and also because its character is system-wide and abstracted from all socio-historical contexts. (Lee and LiPuma, 2004: 148) 
Mathematical finance hence gives rise to a theoretically generated abstract notion of risk (including its various types) that is instrumental in constituting and increasing 'connectivity' among the most diverse financial products.

With respect to the temporality of portfolio theory, Lee and LiPuma (2004: 147) argue that within an investment paradigm which expects future returns, the necessary corollary of Markowitz's portfolio strategy is the ability to calculate future risks: "we find the common assumption that all future events will replicate past events and that the conditions of application are uniform across time and space". Accordingly, many contributions to portfolio theory capitalize on a mathematical modeling of expected risks on the basis of past movements in value and volatility of the assets in question (cf. Levy and Sarnat, 1984; and the contributions in Elton and Gruber, 1979). One major breakthrough in this regard is seen in the options pricing theory suggested by Black and Scholes (1973), which heralded a mathematical modeling of volatility risks of financial investments and used this to price a certain type of derivative instrument, i.e., options (cf. Lee and LiPuma, 2004: 76-82; Millo and MacKenzie, 2003; MacKenzie, 2005).

However, what is important in terms of portfolio theory's temporality is not only that it tends to derive the future from a market model that is assumed to "best describe and predict the behavior of abstract risk by measuring its variability over time" (Lee and LiPuma, 2004: 146), but also that it has an in-built propensity to install synchronism as its logical endpoint. First, portfolio theory, designed to optimize the relationship between risks and profit opportunities from investment, implicitly refers to an ideal state of affairs that lends it its rationale: "The theoretical endpoint [of portfolio theory] was riskless profit, or arbitrage" (Lee and LiPuma, 2004: 78). While Hayek would probably have condemned portfolio theory for its mirage of calculability and its affinity to equilibrium theory (cf. Cooper and Walker, 2011), he explained that only the synchronous moment of opportunity generates exploitable knowledge for market participants who profit from instantly adapting their economic behavior to changes in their environment. Through portfolio theory's risk abstractions, concrete risks of concrete products, which of necessity materialize only in the future, can be treated and traded as if they could be fully controlled and exploited already in the present. Portfolio theory thus advocates synchronism not because arbitrage as such always consists in instant trades. Instead, it allows market participants to position themselves vis-à-vis the market like Hayekian economic subjects, that is, in the "fleeting moment" of arbitrage opportunities (Hayek, 1984a: 214).

\section{Conclusion: The social imaginary of financial synchronism}

As already mentioned, research on the performativity of financial theories and models in the sociology of finance has mostly concentrated on the precise ways in which models do, or do not, have an effect on pricing and trading practices. The notion of performativity was initially celebrated for its genuinely sociological capacity to understand the meaning of economics not in terms of its models' correspondence to reality, but in a way that capitalized on the concrete effects of putting the models to work in pricing and trading. Other voices have since cautioned against an overgeneralization of the performativity theorem by, for instance, highlighting instances of model failure in pricing and trading, or by pointing to the basic distinctions, already referred to, between "theories [of] how the world works" and "theories [of] how to work the world” (Fenton-0'Creevy et al. 2005: 55; Mackenzie et al. 2007).

However, proceeding from the series of examples of economic and financial synchronism presented in this article, I venture a claim that, as it were, is located epistemologically prior to the discussion of the performativity of theories and models in economics and finance. 
Economic and financial synchronism not only consists of theories and models but, more fundamentally, of a certain outlook on the ontology of the social. Here I cannot pay tribute to all the invaluable contributions from cultural history and theory that have highlighted the role of economic thinking as being constitutive of the way in which we understand modern societies (cf. Foucault, 2004; Harvey, 2005), but I would like to stress that I share with these contributions the determination to view economic and financial theory as a particular, and powerful, way of understanding society. The sources of financial synchronism discussed in this article perform a trajectory that interrelates the scientific ambitions of neoclassical economics and finance with much more general claims as to how market participants orient their actions, thus reformulating the ways that societal mechanisms of coordination should be understood. Walras stands at the outset of neoclassical economics' claim toward scientific status, arguing that a focus on pricing can turn economics into an 'exact' science. Portfolio theory and mathematical finance (which incorporates crucial insights from portfolio theory, most notably an abstract notion of risk) have contributed to providing powerful leverage to investors' agency, in particular by making different investments comparable with each other and by effecting the emergence of markets for products that are solely characterized by their particular risk profile. While Hayek remained skeptical regarding the capacity of economics to grasp the dynamics of competitive markets, instead depicting the only guarantee of welfare in the synchronism that competitive markets impose on individuals' actions, he transferred that skepticism into a social theory that disregarded any attempt at coordinated action apart from competitive markets (cf. Davies and McGoey, 2012).

Financial synchronism, I contend, may be understood in terms of Charles Taylor's (2002) notion of 'social imaginaries'. In modernity, scientific understandings are disseminated throughout society, conjuring up representations of 'society' as a whole that inform everyday practices even as they escape the realm of experience. ${ }^{3}$ The practice of reading a news article, for instance, invokes the imaginary of a 'public sphere' or 'societal communication' that has been very important for the constitution of the modern social sciences, sociological and political theory alike. ${ }^{4}$ Although the public sphere can never be observed or verified in its entirety, it is only because of the assumption of a public sphere 'out there' that news article readers can conceive of themselves as being part of the public. A similar mode of actionorientation and meaning making holds for market practices. Taylor (2002) has suggested that 'modern social imaginaries' are, in part, informed by the idea of a 'market' (for instance, in Adam Smith's metaphor of the 'invisible hand') that organizes societal exchange and intercourse, yet which cannot be observed as a whole. With respect to the market, the only device that enables us to 'see' the market is price, yet this depiction of the market in price must assume that prices have been formed on the basis of market exchange, understood as a competition-based pricing mechanism (Hardie, 2004). In other words, while Hayek argues that market prices do not inform individuals, encapsulated as they are in their mundane whereabouts, about the particular processes that brought those prices about, one could argue with reference to Taylor that they still invoke the imaginary of a market 'out there' that, being part of an imaginary of 'society', informs action as well as self-understandings. Thus, the question is how financial synchronism is 'performative' in the sense that it informs economic practices that imply, and put to work, certain imaginary understandings of society.

Through the concept of arbitrage, the transformation of uncertainty into risk (which has been denounced by works in the sociology of finance as a major epistemological fallacy of economic theory [cf. Kessler, 2010, 2013; Lee and LiPuma 2004: 141-50; cf. also O'Malley 2004: 177]), and the invocation of a risk-free investment that escapes the contingencies of temporality, the radical challenge of uncertainty is tamed. The reality of arbitrage thus vouches 
for the viability of the economy even in the face of uncertainty. At the same time, I maintain that the transformation of uncertainty into risk is not only significant because it indicates the hubristic character of any attempt to predict or control the future. It is also significant because, at least in financial economics, the notion of risk was from the very beginning coupled to the promise of the risk-free asset, vouched for by the reality of arbitrage. The economic concept of risk and the promise of freedom from risk through radical synchronism emerged together. This hubris is far more Promethean than the one related to the predictability of the future, because it promises to make all predictions redundant.

Arbitrage as radical synchronism might therefore be paradoxically bound to the selfunderstanding of modern societies as fundamentally and reflexively contingent. No longer is there any standpoint thinkable from which to observe the whole of society in its tendencies toward possible, or threatening, futures, and this fundamental lack of certainty about the future, including chances to steer such tendencies, has entered not only scientific but also vernacular understandings about society. In this constellation, arbitrage appears as an escape lane, hammering home the point that certainty, if unattainable in the future, is at least attainable in the present. At the same time, arbitrage co-constitutes that contingency and uncertainty. On the one hand, and on a 'systemic' or operational level, this applies to the accumulation and cascading of consequences from arbitraging (especially in high frequency and algorithmic trading). On the other hand, arbitrage effectively dramatizes and celebrates the uncertainty of the future, as it is based, conceptually and operationally, on the idea that opportunities for arbitrage open up in unpredictable ways, and that only on this basis they can be exploited. Thus, the point about 'risk' might not only be, as suggested by the sociology of finance, that economics neglects the contingency of the future through the transformation of uncertainty into risk. Rather, as my discussion shows, contingency is made into an ontological presupposition to think society, at the expense of any forward-looking consideration.

\section{Acknowledgments}

This article presents results from an ongoing research project, entitled Polychronicity of the Market: Neoclassical Temporality in Projects of Economic Order Since the 1970s, which I pursue, together with Sebastian Giacovelli, within the framework of the Priority Program 1688 'Ästhetische Eigenzeiten', under grant from the German Research Foundation.

\section{Notes}

1. I, too, have dedicated myself to understanding the relation of financial markets to the future. In an interview project with financial market professionals that I conducted together with Kerstin Schmidt-Beck in the 2000s, our attention was drawn to a certain contradiction that surfaced in many of our interviewees' stories and explanations (see Langenohl and Schmidt-Beck, 2007; Langenohl, 2007; Langenohl, 2008). On the one hand, most of them adhered to an understanding of financial markets as being rational and calculable in the long term, yet it seemed impossible to determine what the 'long term' actually meant. So, while it was always possible to maintain that mispricings would eventually be abolished because the markets return to a 'rational' reflection of the underlying production-based economy, nobody could define what 'eventually' meant. We concluded that an understanding of the long-term rational market might help as some sort of professional premise, in the sense of a 'theory how the world works', but it was surely no 'theory 
how to work the world', which is to say that it was not instrumental to trading (cf. Fenton-0'Creevy et al., 2005: 55). Instead, the same respondents that adhered to the picture of a long-term rational market reported using very short-term-oriented heuristics of a decidedly non-theorized type, which most of them referred to as 'gut feeling'.

2. This also includes a critique of equilibrium theory. See Hayek (1984c: 268-269).

3. For a brief genealogy of the notion of 'social imaginary', see Langenohl (2015: 181-84).

4. On the 'public sphere', see Crossley and Robert (2004); on 'communication', see Park (1924).

\section{References}

Baecker, D. (1999) Die Preisbildung an der Börse. Soziale Systeme, 50(2): 287-312.

Beckert, J. (2014) Capitalist dynamics: Fictional expectations and the openness of the future. MPIfG Discussion Paper, 14/7. KöIn: Max-Planck-Institut für Gesellschaftsforschung.

Beunza, D., Hardie, I., and MacKenzie, D. (2006) A price is a social thing: Towards a material sociology of arbitrage. Organization Studies, 27(5): 721-45.

Beunza, D., Hardie, I., and MacKenzie, D. (2008) The material sociology of arbitrage. In: MacKenzie, D. (ed.) Material Markets: How Economic Agents are Constructed. Oxford: Oxford University Press, 85108.

Bockman, J. (2011) Markets in the Name of Socialism: The Left-wing Origins of Neoliberalism. Stanford, CA: Stanford University Press.

Boy, N. (2015) Sovereign safety. Security Dialogue, 46(6): 530-47.

Callon, M. (2009) Elaborating on the notion of performativity. Le Libellio d'Aegis, 5(1): 18-29.

Černý, A. (2009) Mathematical Techniques in Finance: Tools for Incomplete Markets. Second edition. Princeton, NJ: Princeton University Press.

Cooper, M. and Walker, J. (2011) Genealogies of resilience: From systems ecology to the political economy of crisis adaptation. Security Dialogue, 42(2): 143-60.

Crossley, N. and Roberts, J.M. (eds.) (2004) After Habermas: New Perspectives on the Public Sphere. Oxford: Blackwell.

Davies, W. and McGoey, L. (2012) Rationalities of ignorance: On financial crisis and the ambivalence of neo-liberal epistemology. Economy and Society, 41(1): 64-83.

Dome, T. (1994) History of Economic Theory: A Critical Introduction. Aldershot: Edward Elgar.

Elton, E. J. and Gruber, M.J. (eds.) (1979) Portfolio Theory, 25 Years Later: Essays in Honor of Harry Markowitz. Amsterdam: North-Holland Publishing Company.

Esposito, E. (2010) Die Zukunft der Futures: Die Zeit des Geldes in Finanzwelt und Gesellschaft. Heidelberg: Carl-Auer-Systeme.

Fama, E.F. (1970) Efficient capital markets: A review of theory and empirical work. Journal of Finance, 25(2): 383-417.

Fama, E.F. and Miller, M.H. (1972) The Theory of Finance. New York, NY: Holt, Rinehart and Winston.

Fenton-O'Creevy, M., Nicholson, N., Soane, E. and Willman, P. (2005) Traders: Risks, Decisions, and Management in Financial Markets. Oxford: Oxford University Press.

Foucault, M. (2004) Die Geburt der Biopolitik: Geschichte der Gouvernementalität II. Frankfurt a.M.: Suhrkamp.

Hardie, I. (2004) The sociology of arbitrage: A comment on MacKenzie. Economy and Society, 33(2): 239-54.

Harvey, D. (2005) A Brief History of Neoliberalism. Oxford: Oxford University Press.

Hayek, F.A. von (1984a [1948]) The use of knowledge in society. In: Nishiyama, C. and Leube, K.R. (eds.) The Essence of Hayek. Stanford, CA: Hoover Institution Press, 211-24. 
Hayek, F.A. von (1984b [1978]) Competition as a discovery procedure. In: Nishiyama, C. and Leube, K.R. (eds.) The Essence of Hayek. Stanford, CA.: Hoover Institution Press, 254-65.

Hayek, F.A. von (1984c [1978]) The pretence of knowledge. In: Nishiyama, C. and Leube, K.R. (eds.) The Essence of Hayek. Stanford, CA: Hoover Institution Press, 266-77.

Honegger, C., Neckel, S. and Magnin, C. (2010) Strukturierte Verantwortungslosigkeit: Berichte aus der Bankenwelt. Frankfurt a.M.: Suhrkamp.

Hope, W. (2009) Conflicting temporalities: State, nation, economy and democracy under global capitalism. Time \& Society, 18(1): 62-85.

Hope, W. (2011) Crisis of temporalities: Global capitalism after the 2007-08 financial collapse. Time \& Society, 20(1): 94-118.

Jevons, W.S. (2013 [1871]) The Theory of Political Economy. Houndmills: Palgrave.

Joshi, M. (2003) The Concepts and Practice of Mathematical Finance. Cambridge: Cambridge University Press.

Kessler, O. (2010) Risk. In: Burgess, J. P. (ed.) The Routledge Handbook of New Security Studies. London: Routledge, 17-16.

Kessler, O. (2013) Die Krise als System? Die diskursive Konstruktion von „Risiko“ und „Unsicherheit“. In: Maesse, J. (ed.) Ökonomie, Diskurs, Regierung. Interdisziplinäre Perspektiven. Wiesbaden: VS, 57-76.

Kirchgässner, G. (2008) Homo oeconomicus: Das ökonomische Modell individuellen Verhaltens und seine Anwendung in den Wirtschafts- und Sozialwissenschaften. Tübingen: Mohr/Siebeck.

Langenohl, A. (2007) A critique of organizational capitalism: The enabling fiction of market efficiency in financial professionals' narratives. In: Bazin, L. et al. (eds.) La mondialisation au risque des travailleurs. Paris: L'Harmattan, 219-42.

Langenohl, A. (2008) 'In the long run we are all dead': Imaginary time in financial market narratives. Cultural Critique, 70(10: 3-31.

Langenohl, A. (2010) Analyzing expectations sociologically: Elements of a formal sociology of the financial markets. Economic Sociology: The European Economic Newsletter, 12(1): 18-27.

Langenohl, A. (2015) Town Twinning, Transnational Connections and Trans-local Citizenship Practices in Europe. Basingstoke: Palgrave Macmillan.

Langenohl, A. and Schmidt-Beck, K. (2007) Technology and (post-)sociality in the financial market: A reevaluation. Science, Technology and Innovation Studies, 3(1): 5-22.

Lee, B. and LiPuma, E. (2002) Cultures of circulation: The imaginations of modernity. Public Culture, 14(1): 191-213.

Lee, B. and LiPuma, E. (2004) Financial Derivatives and the Globalization of Risk. Durham, NC: Duke University Press.

Lépinay, V.-A. (2007) Parasitic formulae: The case of capital guarantee products. In: Callon, M. and Millo, Y. (eds.) Market Devices. Oxford: Blackwell, 261-83.

Levy, H. and Sarnat, M. (1984) Portfolio and Investment Selection: Theory and Practice. Englewood Cliffs, NJ: Prentice-Hall.

Leyshon, A. and Thrift, N. (2007) The capitalization of almost everything: The future of finance and capitalism. Theory, Culture \& Society, 24(7-8): 97-115.

Lounsbury, M. (2002) Institutional transformation and status mobility: The professionalization of the field of finance. Academy of Management Journal, 45(1): 255-66.

Lounsbury, M. (2007) A tale of two cities: Competing logics and practice variations in the professionalizing of mutual funds. Academy of Management Journal, 50(2): 289-307.

Mackenzie, D. (2005) Opening the black boxes of global finance. Review of International Political Economy, 12(4): 555-76. 
MacKenzie, D. et al. (eds.) (2007) Do Economists Make Markets? On the Performativity of Economics. Princeton, NJ: Princeton University Press

Markowitz, H. (1952) Portfolio selection. The Journal of Finance, 7(1): 77-91.

Markowitz, H. (1991) Portfolio Selection: Efficient Diversification of Investments. Oxford: Basil Blackwell.

Mattick, P. (1973) Die Marxsche Arbeitswertheorie und das Wert-Preis-Problem. In: Eberle, F. (ed.) Aspekte der Marxschen Theorie I. Zur methodischen Bedeutung des 3. Bandes des 'Kapital'. Frankfurt a.M.: Suhrkamp, 337-62.

Millo, Y. and MacKenzie, D. (2003) Constructing a market, performing theory: The historical sociology of a financial derivatives exchange. American Journal of Sociology, 109(1): 107-45.

Oetsch, W.O. (2013) The deep meaning of 'market': Understanding neoliberal market-reasoning. Human Geography, 6(2): 11-25.

O'Malley, P. (2004) Risk, Uncertainty and Government. Portland, OR: Glasshouse Press.

Park, R. (1924) Sociology and the social sciences. In: Park, R. and Burgess, E. (eds.) Introduction to the Science of Sociology. Chicago, IL: University of Chicago Press, 1-63.

Preda, A. (2009) Framing Finance: The Boundaries of Markets and Modern Capitalism. Chicago, IL: University of Chicago Press.

Pribram, K. (1998) Geschichte des ökonomischen Denkens. Frankfurt a.M.: Suhrkamp.

Strulik, T. (2006) Introduction. In: Strulik, T. and Wilke, H. (eds.) Towards a Cognitive Mode in Global Finance. Frankfurt: Campus, 9-32.

Strulik, T. and Wilke, H. (eds.) (2006) Towards a Cognitive Mode in Global Finance. Frankfurt: Campus. Taylor, C. (2002) Modern social imaginaries. Public Culture, 14(1): 91-124.

Vogl, J. (2010) Das Gespenst des Kapitalismus. Zürich: Diaphanes.

Walras, L. (1954 [1926]) Elements of Pure Economics, or The Theory of Social Wealth, translated by W. Jaffé. Homewood, IL: Irwin.

Wieser, F. von (1989 [1893]) Natural Value. Fairfield, NJ: Augustus M. Kelley. 